\title{
Wyrok biskupa płockiego Pawła Giżyckiego w sporze pomiędzy Ninogniewem Kryskim a Bogusławem, plebanem w Drobinie
}

Key words: medieval Western Mazovia, medieval polish Church, medieval polish nobility.

Burzliwe dzieje Mazowsza sprawiły, iż do naszych czasów nie zachowało się zbyt wiele średniowiecznych źródeł dokumentowych i aktowych dotyczących tej dzielnicy ${ }^{1}$. Źródła dokumentowe zostały opublikowane drukiem w sposób systematyczny do roku $1381^{2}$. Dokumenty z okresu późniejszego były wydawane wybiórczo - bądź na zasadzie tematycznej ${ }^{3}$, bądź na zasadzie dość przypadkowego doboru ${ }^{4}$. Natomiast zakres edycji kościelnego materiału aktowego, a więc ksiag kapitulnych, konsystorskich i biskupich dla interesującego nas

1 Szerzej na temat strat materiałów rękopiśmiennych na Mazowszu zob. wstęp do Nowy kodeks dyplomatyczny Mazowsza [dalej: NKDM], cz. II, Warszawa 1989, s. IV-V.

2 Zob. CDMG; NKDM, cz. II-III. Warto zaznaczyć, iż do tomu III NKDM ukazały się trzy uzupełnienia, zob. A. Supruniuk, Uzupetnienia i uwagi do Nowego kodeksu dyplomatycznego Mazowsza część III: dokumenty z lat 1356-1381, SŹ 2002, t. XL, s. 107-165; K. Pacuski, Uzupetnienia i sprostowania do Nowego kodeksu dyplomatycznego Mazowsza część III: dokumenty z lat 1356-1381, SŹ 2002, t. XL, s. 167-200 oraz J. Grabowski, Jeszcze uzupetnienia do Nowego Kodeksu dyplomatycznego Mazowsza, część III: dokumenty z lat1356-1381, SŹ 2003, t. XLI, s. 71-76.

3 Iura Masoviae terrestria, t. I-III, Warszawa 1972-1974; Zbiór dokumentów i listów miasta Płocka, t. I-II, Warszawa 1975-1987.

4 Kodeks dyplomatyczny Księstwa Mazowieckiego obejmujaca bulle papieżów, przywileje królów polskich i ksiażat mazowieckich tudzież nadania tak korporacyj jako i osób prywatnych, wyd. J.T. Lubomirski, Warszawa 1863; DKM. 
obszaru jest bardzo skromny ${ }^{5}$. Wskutek takiej sytuacji materiały czternasto- i piętnastowieczne zostały opublikowane tylko częściowo, co czyni zasadną edycję publikowanego tu źródła.

Aktualnie jest ono przechowywane w zasobie Archiwum Diecezjalnego w Płocku w zespole Acta Episcopalia. Interesujący nas wyrok biskupa płockiego Pawła Giżyckiego został zapisany w pierwszym tomie akt czynności biskupich obejmujacych lata 1448-1471 na karcie $21^{6}$. Sentencja biskupia zachowała się w całości. Brak jest jakichkolwiek zniszczeń wspomnianej karty. Opisu tej księgi dokonał ostatnio Paweł Chojnacki, w związku z czym ograniczę się do prezentacji jego ustaleń. Księga czynności biskupich nosząca sygnaturę Ep. 1 zawiera zapisy czynności, które były dokonywane przez biskupa, bądź w jego obecności, oraz akta sądowe. W księdze tej brak jest składek z drugiej połowy roku 1454 oraz z dwóch następnych lat, tzn. 1455 i 1456 r. Każdy nowy rok w księdze rozpoczynał się od podania roku, imienia papieża oraz roku jego pontyfikatu. Każdą sprawę oddzielano od siebie nagłówkiem (tytułem) - zazwyczaj nazwą miejscowości, której sprawa dotyczyła. Wpisy w zasadzie były ułożone chronologicznie, aczkolwiek zdarzały się w tej materii pewne wyjątki. Nową sesję sądową oznaczano niewielkim inicjałem. Zazwyczaj tylko przy pierwszej sprawie w danej sesji podawano datę i miejsce. Pisarzem, który głównie prowadził wpisy do księgi o sygnaturze Ep. 1, był Przecław z Jączewa ${ }^{7}$.

Właściwie niewiele wiadomo o dziejach Drobina w średniowieczu ${ }^{8}$. Pierwsza wzmianka traktująca o istnieniu w tej miejscowości struktur kościelnych jest nader lakoniczna. W testacji dokumentu wystawionego w Płocku 2 lutego 1333 r. przez biskupa płockiego Floriana widnieje Herman pleban w Drobinie, który zarazem był kanonikiem płockim .

5 Acta capitulorum nec non iudiciorum ecclesiasticorum selecta, t. III, cz. I: Acta iudiciorum dioecesum Plocensis, Wladislaviensis et Gneznensis (1422-1533), Kraków 1908.

6 Archiwum Diecezjalne w Płocku [dalej: ADP], Acta Episcopalia [dalej: Ep.], sygn. 1, k. 21.

7 P. Chojnacki, Biskup płocki Pawet Giżycki (1439-1463) i jego działalność [w:] Z biografistyki Polski późnego średniowiecza. Studia, red. M. Koczerska, Warszawa 2001 (,Fasciculi historici novi”, t. IV), s. 136-137.

$8 \quad \mathrm{Z}$ racji braku zainteresowania historyków średniowiecznymi dziejami Drobina jedynie Stownik historyczno-geograficzny województwa płockiego w średniowieczu (z. 1, oprac. A. Borkewicz-Celińska, Wrocław 1980, s. 63-64) przynosi informację o tej miejscowości. Z tego powodu będzie on dla nas przewodnikiem po zachowanych do naszych czasów archiwaliach traktujących o Drobinie.

9 NKDM, t. II, nr 204. Następnie Herman przed 23.06.1339 r. został oficjałem biskupim, który to urząd dowodnie dzierżył jeszcze 15.03.1344 r., zob. A. Radzimiński, 
Wygląda jednak na to, że beneficjum drobińskie musiało być w tym czasie bardzo intratne, skoro w jego posiadanie wszedł przedstawiciel kapituły płockiej. Następnie przez wiele lat źródła milczą o parafii drobińskiej.

Wiadomo natomiast, że w 1444 r. Andrzej z Zakrzewa i Piotr z Gulczewa sprzedali swoje części w Drobinie i Brwilnie dwóm braciom, Ninogniewowi i Pawłowi Kryskim, za sumę 200 grzywien $^{10}$. Następnie w wyniku podziału dóbr 6 czerwca 1449 r. pomiędzy braćmi Kryskimi z Gradzanowa w posiadanie Ninogniewa weszły: Drobin, Nowa Wieś, Kosmenin, Krysk, Strzembowo, Drochowo, Dłutowo oraz Krzewo. Z kolei Paweł stał się właścicielem: Gradzanowa, Siemiątkowa, Krzeczanowa, Cyndatów oraz Brwilna ${ }^{11}$. Nie wiemy, kiedy wystapiły pierwsze spory pomiędzy Kryskim a miejscowym plebanem. Niemniej zważywszy na fakt, iż w treści sentencji nie natrafiamy na żaden ślad wskazujący na zaangażowanie w ten konflikt Pawła Kryskiego, nastąpiło to zapewne wkrótce po tym, gdy Ninogniew został samodzielnym właścicielem części Drobina. Finałem kontrowersji pomiędzy dziedzicem i plebanem było zdanie się na sąd biskupa płockiego Pawła Giżyckiego, którego orzeczenie stanowi przedmiot niniejszej edycji.

Zarówno biskup płocki, jak i Ninogniew z Kryska sa dobrze znani w literaturze przedmiotu. Pierwszy z nich, Paweł Giżycki, herbu Gozdawa, był synem sędziego ziemskiego sochaczewskiego Wacława, który uchodzi za pierwszego przedstawiciela rodziny Giżyckich pełniącego znaczący urząd. Paweł prawdopodobnie urodził się na przełomie XIV/XV w. Już w 1419 r. ukończył studia w Pradze, wieńcząc je uzyskaniem tytułu bakałarza nauk wyzwolonych. Następnie wszedł w posiadanie wielu beneficjów kościelnych, m.in. dzięki dobrym kontaktom ze Zbigniewem Oleśnickim. Był kolejno kanonikiem krakowskim, gnieźnieńskim i poznańskim, scholastykiem płockim i krakowskim oraz od 1439 r. biskupem płockim, którym pozostał aż do swojej śmierci w 1463 r. Warto także dodać, że w latach dwudziestych XV w. sprawował urząd pisarza ziemskiego krakowskiego ${ }^{12}$.

Z kolei Ninogniew Kryski, syn Leona, posługiwał się herbem Prawda. Począwszy od 1434 r. piął się po szczeblach kariery

Prałaci i kanonicy kapituły katedralnej płockiej $w$ XIV i I pot. XV w. Studium prozopograficzne, t. II: Kanonicy, Toruń 1993, s. 57, nr 50.

10 AGAD, Metryka Koronna, t. 337, k. 132v.

11 Ibidem, k. 74.

12 T. Słowikowski, Giżycki Pawet h. Gozdawa (zm. 1463) [w:] PSB, t. VIII, Wrocław 1959, s. 23-25; zob. również P. Chojnacki, Biskup płocki..., s. 87-187; Urz. mp., s. 83 (tam potwierdzony w roli pisarza ziemskiego krakowskiego w końcu 1424 r.). 
urzędniczej, zdobywając kolejne godności. W latach 1434-1457 był podsędkiem płockim, następnie chorążym zakroczymskim (1439-1450), sędzią wyszogrodzkim i zakroczymskim (1450-1462), sędzia płockim (1457-1467/8), kasztelanem płockim (1463-1465), a uwieńczeniem jego kariery była godność wojewody płockiego (1465-1467/8) dzierżona przezeń do śmierci, która nastapiła przed 1468 r., gdyż w tymże roku po raz pierwszy źródła wspomniały go jako zmarłego ${ }^{13}$.

Niestety, niewiele wiadomo o magistrze Bogusławie, plebanie w Drobinie. Na tym beneficjum był potwierdzony od 1448 r. $^{14}$ Ponadto z pewnością ukończył on studia na którymś z ówczesnych uniwersytetów, o czym przekonuje nas tytuł magister. Zmarł przed 15 września 1451 r., gdyż wtedy to patron i kolator kościoła w Drobinie Ninogniew Kryski prezentował na plebanię drobińską swojego syna Łazarza ${ }^{15}$.

Należy podkreślić, że biskup płocki Paweł Giżycki w interesującym nas sporze pełnił funkcję sędziego polubownego. Wskutek oddania sprawy pod sąd biskupi Ninogniew miał dać Kościołowi drobińskiemu jedną włókę wolną od robót i czynszów, położoną między włókami kmiecymi, a także przekazać Bogusławowi w dożywocie karczmę. Pleban zaś w zamian za uzyskane nadania z karczmy miał Kryskiemu, na wzór innych karczmarzy drobińskich, albo płacić czynsz taki sam jak pozostali karczmarze, albo ustalona kwotę od wyszynku piwa. Ponadto Bogusław z racji otrzymanej włóki został zobowiązany przez ordynariusza, rozstrzygajaccego zaistniały spór, do odprawiania osobiście lub poprzez innego kapłana trzech mszy w tygodniu (dwóch za zmarłych oraz jednej za grzechy Ninogniewa i jego bliskich). Postanowień wyroku winny się trzymać obie strony pod kara 100 florenów nałożonych przez sędziego. W przypadku naruszenia warunków, które zostały przyjęte przez obie zwaśnione strony, połowa wspomnianej sumy miała przypaść Kościołowi, zaś pozostałe 50 florenów stronie poszkodowanej.

13 A. Wolff, Studia nad urzędnikami mazowieckimi 1370-1526, Wrocław 1962, s. 88, 147, 235, 284, 288-290, 293; E. Rostworowski, Kryski Ninogniew h. Prawdzic (pot. XVw.) [w:] PSB, t. XV, Wrocław 1970, s. 485; J. Piętka, Mazowiecka elita feudalna późnego średniowiecza, Warszawa 1975, s. 85-86.

14 ADP, Ep., sygn. 1, k. 6v.

15 Ibidem, k. 57v. 
Dokument

Wyrok biskupa płockiego Pawła Giżyckiego w sporze pomiędzy Ninogniewem z Kryska, chorażym wyszogrodzkim i podsędkiem płockim, a magistrem Bogustawem, plebanem w Drobinie.

Oryg.: Archiwum Diecezjalne w Płocku, Acta Episcopalia, sygn. Ep. 1, k. 21.

Wzm.: Stownik historyczno-geograficzny województwa płockiego w średniowieczu, z. 1. oprac. A. Borkowska-Celińska, Wrocław 1980, s. 64 .

Uwaga: Tekst dokumentu wydany wedtug zasad zawartych [w:] A. Wolff, Projekt instrukcji wydawniczej dla pisanych źródet historycznych do połowy XVI wieku, SŹ, t. I, 1957.

\section{Tytut: Drobnino}

In causa generosi domini Nynognei de Kriszko ${ }^{1}$ vexilliferi Wyschegradensis et subiudicis Plocensis cum discreto magistro Boguslao $^{2}$ plebano de Drobnino ${ }^{3}$ dominus episcopus ${ }^{4}$ per sentenciam suam arbitralem, vigore compromissi in eum facti prolatam, sentenciavit et pronunciavit in primis videlicet, quod idem dominus Nynogneus vexillifer tenebitur dare et assignare unum mansum agri in Drobnino predictam, inter mansos kmethonum in ibidem iacentem, ita tamen, quod idem mansus non sit finalis, cum area et aliis pertinenciis ad dictum mansum spectantibus pro ecclesia in Drobnino et suis rectoribus pro tempore existentibus ad tempora perpetua, ab omnibus laboribus, censibus, solucionibus, angariis et preangariis universis liberum penitus et exemptum. Item pari sua sentencia pronunciavit, quod idem nobilis dabit unam thabernam ibidem in Drobnino prefato magistro Boguslao plebano in ibidem, dumtaxat ad tempora vite ipsius plebani, cum omnibus similiter utilitatibus et redditibus universis, caldari tunc excepto, a quo idem thabernator more aliorum thabernatorum in dicta Drobnino existencium prefato nobili censum solvet sive precium consuetum circa cervisie braxeacionem. Item ${ }^{a}$ idem magister Boguslaus plebanus modernus et successores sui pro tempore, racione huiusmodi mansi agri, leget tres missas singulis septimanis quolibet anno per se vel alium presbiterum: duas pro defunctis et terciam pro peccatis ipsius nobilis et suorum propinquorum, ad quod ipsum dictus dominus episcopus, ut arbiter et ordinarius 
loci, simili sentencia sua compulit et astrinxit. Que omnia partes predicte tenere debent sub pena centum florenorum per dominum vallata, medietatem pro $^{b}$ ecclesia et mediatem pro parte tenente. Quam sentenciam et penam partes eadem approbarunt et emologarunt, presentibus dominis quibus supra.

a Et przekreślone.

b Wyraz jest poprawiany.

Ninogniew z Kryska h. Prawda, zob. tekst główny.

Bogustaw, pleban w Drobinie, zob. tekst główny.

3 Drobin, wieś, dawniej powiat bielski. Obecnie gmina Drobin, powiat płocki, województwo mazowieckie.

4 Pawet Giżycki h. Gozdawa, zob. tekst główny.

\section{Abstract \\ The Judgement of the Bishop of Płock, Paweł Giżycki, on the Dispute between Ninogniew Kryski and Bogusław, Parson in Drobin}

The unpublished judgement from the books of the activities of the bishops of Płock is one of few medieval sources on the history of the Drobin parish. It was issued in Płock on February 5, 1449, by the bishop Pawel Giżycki, in the case of the dispute between the heir of Drobin, Ninogniew Kryski, and its parson, Bogusław. On its basis, Ninogniew was to present the church in Drobin with one volok free from labour and rent, located among the peasant voloks, as well as to give Bogusław an inn for life. In return, the parson was to pay him the same rent as other innkeepers in Drobin or a fixed sum from the sales of beer. Moreover, having been given the volok, Bogusław was obliged by the bishop who settled the dispute to perform personally or through another priest three masses a week (two for the dead and one for the sins of Ninogniew and his loved ones). 